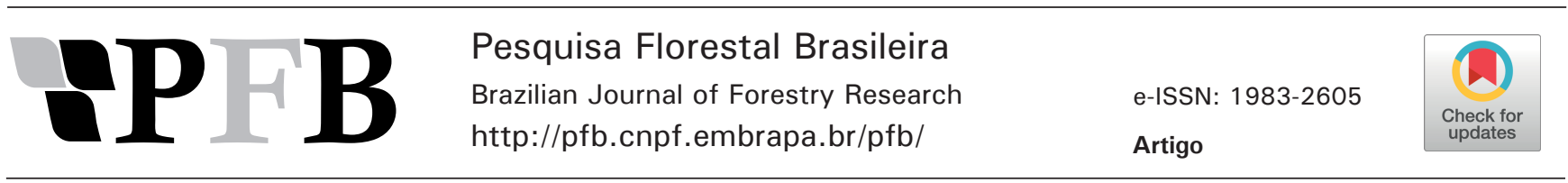

\title{
Fruits and seeds biometry and germination of Astrocasia jacobinensis
} Héveli Kalini Viana Santos ${ }^{1}$ (D), Andrea Vita Reis Mendonça ${ }^{1}\left(\mathbb{D}\right.$, Iracema Gomes da Silva ${ }^{1}$, Darlene Pereira da Silva ${ }^{1}$ (D),
Manuela Oliveira de Souza *(iD)

${ }^{1}$ Universidade Federal do Recôncavo da Bahia, Av. Rui Barbosa, 710, Centro, CEP 44380-000, Cruz das Almas, BA, Brazil

"Corresponding author:

manuelasouza@ufrb.edu.br

Index terms:

Forest species

Phyllantaceae

Seed germinability

Termos para indexação:

Espécie florestal

Phyllantaceae

Capacidade germinativa das sementes

Received in 06/02/2018

Accepted in 12/03/2019

Published in 23/05/2019

doi: 10.4336/2019.pfb.39e201801570

\begin{abstract}
The objective of this study was to biometrically characterize fruits and seeds of Astrocasia jacobinensis. We also aimed to evaluate the germination potential according to the fruit color and to determine the optimal temperature for germination tests. Fruits were harvested from 4 matrices trees in the Environmental Protection Area of "Lago de Pedra do Cavalo", Bahia, State, Brazil. The fruits were used to install two experimental areas. In the first one we evaluated the germinative behavior according to fruit color using four replicates. The second experiment was used to test the optimal germination temperature, with tests conducted under constant temperatures $(15,25,30$, $\left.35^{\circ} \mathrm{C}\right)$ and alternating temperatures $\left(25-30\right.$ and $\left.15-30{ }^{\circ} \mathrm{C}\right)$, using four replicates per treatment. Evaluations for both experiments were performed daily. The fruits presented a mean size of $7.5 \mathrm{~mm}$ in length and $9.6 \mathrm{~mm}$ in diameter. The seeds were circular with a mean diameter of $3.52 \mathrm{~mm}$. Green fruits have seeds with better germination potential. For future germination tests within this species we recommend a temperature within the range $25^{\circ} \mathrm{C}$ to $30^{\circ} \mathrm{C}$.
\end{abstract}

\section{Biometria de frutos e sementes e germinação de Astrocasia jacobinensis}

Resumo - O objetivo neste trabalho foi caracterizar biometricamente os frutos e as sementes de Astrocasia jacobinensis (Müll.Arg.), avaliar o potencial germinativo em função da cor do fruto e definir a temperatura ideal para testes de germinação. Os frutos foram colhidos de 4 árvores matrizes na Área de Proteção Ambiental do Lago de Pedra do Cavalo, BA, sendo usados para a instalação de dois experimentos. No primeiro foi avaliado o comportamento germinativo em função da cor dos frutos (verdes ou marrons) utilizando-se quatro repetições. No segundo testou-se a temperatura ótima de germinação, com testes conduzidos sob temperaturas constantes $(15,25,30,35$ ${ }^{\circ} \mathrm{C}$ ) e alternadas $\left(25-30\right.$ e $\left.15-30{ }^{\circ} \mathrm{C}\right)$, utilizando-se quatro repetições por tratamento. As avaliações para ambos os experimentos foram realizadas diariamente. Os frutos apresentavam dimensões médias de 7,5 mm de comprimento e 9,6 mm de diâmetro. As sementes eram circulares, com diâmetro médio de $3,52 \mathrm{~mm}$. Os frutos verdes apresentaram sementes com melhor potencial germinativo. Testes de germinação de A. jacobinensis devem ser conduzidos sob temperatura entre $25^{\circ} \mathrm{C}$ a $30^{\circ} \mathrm{C}$. 


\section{Introduction}

Given the current legislative scenario and environmental policy in Brazil, the need for forest conservation and restoration of environmentally degraded areas has been a priority, promoting a growing demand for seeds of native forest species (Silva et al., 2017). This demand aims to fulfill the conservation programs and the production of commercial forests, considering that this input is essential for the restoration and conservation of ecosystems.

Oliveira (2009) emphasizes the need for technical knowledge to subsidize germination tests as they are essential for the characterization of seed lots.

The analysis of the composition of these lots in Brazil follows the procedures established by the Rules for Seed Analysis (Brasil, 2009) in order to standardize the results. In these standards the ideal conditions for the development of numerous species were described, although only a small proportion of these are addressed to Brazilian native trees species (Oliveira et al., 2008). So there is a gap for specific standards regarding these wide diversity of native forest species (Brasil, 2013).

Astrocasia jacobinensis (Müll. Arg.) G.L.Webster is popularly known as catuaba-braba or jacobina. It is constituted by five neotropical species, closely related to Phyllanthus, differing from this one because it presents pistil flowers with corolla well developed (Webster, 1992). Nowadays, it forms the family Phyllantaceae, being previously connected to the family Euphorbiaceae. Thus, it is not uncommon to find it under this classification, as in Jimenez and Gordillo (2001), Gordillo et al. (2002), Juncá et al. (2005), Siqueira-Filho et al. (2009).

In Brazil the occurrence was registered for only one species of this genus, Astrocasia jacobinensis. It can behave both as shrub (Silva \& Sales, 2004) and tree shape, reaching up to $6 \mathrm{~m}$ in height. It is usually inventoried in semideciduous and deciduous seasonal forests (Cardoso et al., 2009; Flora do Brasil, 2017; Souza et al., 2018; ), but it can be also found, not frequently, in areas of Caatinga (Silva \& Sales, 2004; Juncá et al., 2005; Associação Plantas do Nordeste, 2015).

Numerous floristic surveys indicate the occurrence of A. jacobinensis in the states of Bahia (Juncá et al., 2005; Cardoso et al., 2009; Souza et al. 2018; Flora do Brasil, 2017), Pernambuco (Silva \& Sales, 2004; Siqueira-Filho et al., 2009; Flora do Brasil, 2017), Ceará (Ribeiro \&
Loiola, 2016), Sergipe (Brasil, 2012), Rio de Janeiro (Flora do Brasil, 2017) and Minas Gerais (Oliveira Filho et al., 2008).

Considering the scarcity of studies related to silviculture of native species, the objective of this study was to characterize fruits and seeds, to evaluate the germination potential of the seeds as a function of the color of the fruit and to define the optimal temperature for germination and post-seminal development of $A$. jacobinensis.

\section{Material and methods}

The fruits of Astrocasia jacobinensis were collected in October 2016 from four matrices trees, distributed with distances between 2 and $52 \mathrm{~m}$ apart from each other (Table 1). The trees were recorded during a floristic survey in the Environmental Protection Area (EPA) of Lago de Pedra do Cavalo, Bahia State, Brazil (Souza et al., 2018). The EPA area is 30,156 ha, within the coordinates $39^{\circ} 20^{\prime} 00^{\prime \prime}$ and $38^{\circ} 55^{\prime} 00^{\prime \prime} \mathrm{W} ; 12^{\circ} 10^{\prime} 00^{\prime \prime}$ and $12^{\circ} 40^{\prime} 00^{\prime \prime} \mathrm{S}$.

Table 1. Location of sampling matrices trees for seeds of Astrocasia jacobinensis in the Environmental Protection Area of Lago de Pedra do Cavalo, Bahia State, Brazil.

\begin{tabular}{ccc}
\hline Matrice tree & Latitude & Longitude \\
\hline 1 & $12^{\circ} 23^{\prime} 43.3^{\prime \prime} \mathrm{S}$ & $39^{\circ} 01^{\prime} 47.5^{\prime \prime} \mathrm{W}$ \\
2 & $12^{\circ} 23^{\prime} 43.3^{\prime} \mathrm{S}$ & $39^{\circ} 01^{\prime} 47.7^{\prime \prime} \mathrm{W}$ \\
3 & $12^{\circ} 23^{\prime} 43.0^{\prime \prime} \mathrm{S}$ & $39^{\circ} 01^{\prime} 47.8^{\prime \prime} \mathrm{W}$ \\
4 & $12^{\circ} 23^{\prime} 41.8^{\prime} \mathrm{S}$ & $39^{\circ} 01^{\prime} 49.2^{\prime \prime} \mathrm{W}$ \\
\hline
\end{tabular}

According to Köppen-Geiger (Alvares et al., 2013), the climate in the region is classified as As - Tropical climate with dry summer, with 24 to $26{ }^{\circ} \mathrm{C}$ of annual average range of temperature, minimum of 15.5 ${ }^{\circ} \mathrm{C}$ and maximum of $32.6{ }^{\circ} \mathrm{C}$ (Instituto Nacional de Meteorologia, 2017) and a rainfall volume of 700 to $1,000 \mathrm{~mm}^{\text {year }}{ }^{-1}$.

After harvested, the fruits were taken to the Ecology and Forest Restoration Laboratory, from Federal University of Reconcavo of Bahia, in Cruz das Almas Campus, BA, where they were characterized, measured and manually benefited. The fruits were characterized morphologically considering the following aspects: type, color, dimensions, texture and number of seeds per fruit.

To obtain fruit weight, we used six replicates of 100 units per matrice. The number of healthy and non-healthy seeds was also evaluated, keeping them separated by 
color. A random sample of 100 fruits from each matrice was used to measure length and width using a precision digital caliper of $0.01 \mathrm{~mm}$.

After characterization, the fruits of the four matrices were mixed and benefited, splitting in two groups: seeds originated from green and brown fruits (Figure 1). Seeds were characterized by the weight of 1,000 seeds (Brasil, 2009) and by their dimensions (length and width), that were measured with a digital caliper of $0.01 \mathrm{~mm}$ precision.
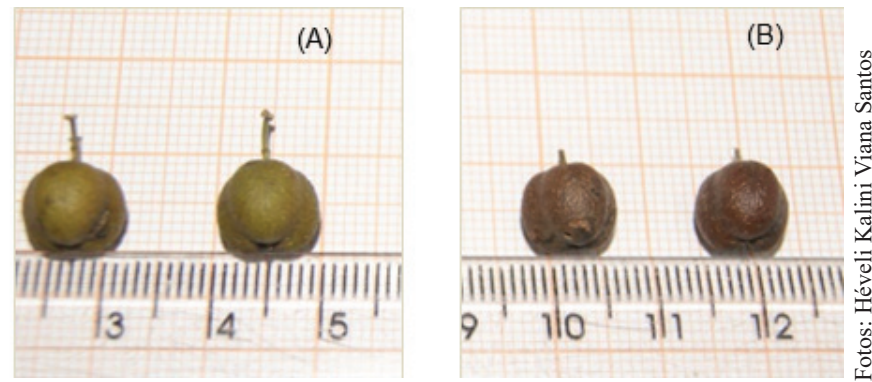

Figure 1. Fruits of Astrocasia jacobinensis: green (A) and brown (B) collected in the Environmental Protection Area of Lago de Pedra do Cavalo, Bahia State, Brazil.

For the biometry of fruits and seeds, confidence intervals $(\alpha=0.05)$ were carried out for the 100 fruit mass (FM 100), fruit main axis length (FL), fruit diameter (FD), total seeds in 100 fruits (TS 100), percentage of healthy seeds in 100 fruits ( $\% \mathrm{HS})$, mass of 1,000 seeds (MS 1000) and mean seed diameter (MSD).

To evaluate seeds germination as a function of fruit color (green and brown) we used 80 seeds divided into four replicates, distributed on towel paper in roll, moistened with distilled water. Each replicate was conditioned in polyethylene bags and kept in a biochemical oxygen demand (BOD) incubator, with a controlled and constant temperature of $25^{\circ} \mathrm{C}$ (Brancalion et al., 2010) and photoperiod of $8 \mathrm{~h}$ of light daily (Lima et al., 2017).

In the germination tests, the counts were performed daily, evaluating the number of germinated seeds; normal, abnormal and dead seedlings; and dead and hard seeds. Seeds were considered germinate when radicle protrusion was present (Bewley et al., 2013). Normal seedlings were considered the ones that presented all well-developed essential structures (Brasil, 2009). Length of the aerial part and the primary root were measured of all normal seedlings with a ruler.

During the germination tests we evaluate: average time (AT), germination rate (GR) and time intervals between $16 \%$ and $84 \%$ of viable seed germination $\left(\mathrm{U}_{8416}\right)$ (Bewley et al., 2013); average length of aerial part (LAP) and primary root (R) of normal seedlings, considering the initial number of seeds (Guedes et al., 2009); synchronization index (Santana \& Ranal, 2004), percentage of germination ( $\% \mathrm{G})$, formation of normal seedlings ( $\%$ normal) and ratio of normal on germinated seedlings $(\mathrm{N} / \mathrm{G})$.

Constant temperatures of $15,25,30,35{ }^{\circ} \mathrm{C}$ and alternating temperatures between $25-30{ }^{\circ} \mathrm{C}$ and 15 $30{ }^{\circ} \mathrm{C}$ were tested in a completely randomized design containing four replicates of 25 seeds. The assemblies of germination tests, as well as the procedures for counting and obtaining the variables were performed as previously described to evaluate the germination potential according to fruit color. Variance analysis $(\alpha=0.05)$ and tests of multiple comparisons of means were carried out using R Program version 3.1.3 (R Development Core Team, 2015). When the assumptions of the analysis of variance were not met, we used data transformation.

\section{Results}

Astrocasia jacobinensis has dry, woody, coconut-like type fruit (Figure 2A), predominantly tricoccus (Figure 2B), with the eventual occurrence of four loci, with one seed per loci (Figure 2C).

The coccus are evident and present a longitudinal suture line, slightly protruding. They are being separated by lines of fissure that go from the basis to the apex of the fruit. The fruits are circular with main axis length of $7.5 \pm 0.04 \mathrm{~mm}$ and diameter of $9.6 \pm 0.04 \mathrm{~mm}$ (Table 2). The seeds are circular with average diameter of 3.52 $\pm 0.07 \mathrm{~mm}$ (Table 2).

One kilogram of fruit contains about 3,678 fruits and 1,556 healthy seeds, which is equivalent to approximately $31.5 \mathrm{~g}$ of seeds, considering that the average weight of one thousand seeds corresponds to $20.25 \mathrm{~g}$ (Table 2).

Each fruit can contain from zero to four seeds, but this last state is rare and it was observed in only one fruit of matrice 4 . The number of seeds per fruit was differentiated between matrices (Chi-Square $=107.28$, significance $=2 * 10^{-16}$ ). It was observed that matrice 4 presented a higher proportion of fruits with a higher number of seeds, commonly two seeds, in relation to the other matrices (Figure 3). In matrices 1, 2 and 3 there was a predominance of fruits with one seed or they were 
empty. Fruits with three seeds were more abundant in matrice $4(17 \%)$. In the other matrices only $3 \%$ of the fruits contained three seeds.

The seeds from fruits of green collor presented higher germination performance, evidenced by the lower average germination time (8.3), larger length of shoot $(1.53 \mathrm{~cm})$, normal seedling root $(1.66 \mathrm{~cm})$, higher percentage of germination $(82.5 \%)$ and formation of normal seedlings $(70.0 \%)$ (Table 3$)$.
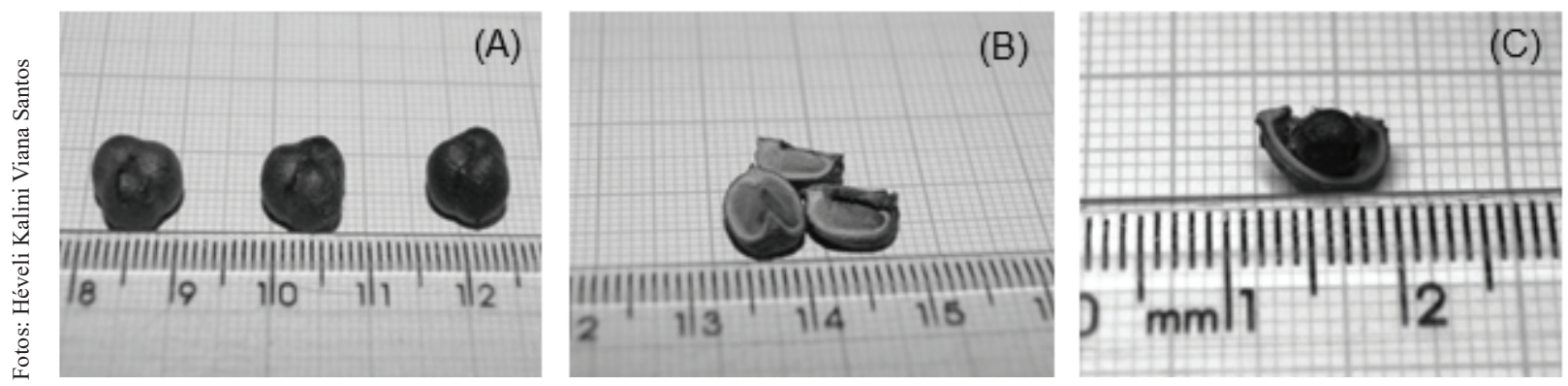

Figure 2. Fruit of the coccus type (A) of Astrocasia jacobinensis collected in the Environmental Protection Area of Lago de Pedra do Cavalo, Bahia State, Brazil, with detail of the loci (B) and the presence of one seed per loci (C).

Table 2. Biometry of Astrocasia jacobinensis fruits collected in the Environmental Protection Area of Lago de Pedra do Cavalo, Bahia State, Brazil.

\begin{tabular}{|c|c|c|c|c|c|c|c|c|}
\hline & & FM $100(g)$ & TS 100 & $\%$ HS 100 & MS 1000 (g) & FL $(\mathbf{m m})$ & FD (mm) & $\operatorname{MSD}(\mathbf{m m})$ \\
\hline \multirow{5}{*}{ Matrice 1} & Sample size (n) & 6 & 6 & 6 & IN & 99 & 99 & 40 \\
\hline & Average & 26.18 & 69 & 16 & IN & 7.86 & 9.11 & 3.50 \\
\hline & Mean standard error & 0.17 & 4 & 5 & IN & 0.04 & 0.05 & 0.03 \\
\hline & Lower limit (IC) & 25.76 & 58 & 3 & IN & 7.79 & 9.02 & 3.43 \\
\hline & Upper Limit (IC) & 26.61 & 79 & 28 & IN & 7.93 & 9.21 & 3.57 \\
\hline \multirow{5}{*}{ Matrice 2} & Sample size (n) & 1 & 1 & 1 & & 100 & 100 & 6 \\
\hline & Average & 23.7 & 78.0 & 7.7 & IN & 7.36 & 9.03 & 3.13 \\
\hline & Mean standard error & NI & IN & IN & IN & 0.04 & 0.04 & 0.15 \\
\hline & Lower limit (IC) & IN & IN & IN & IN & 7.29 & 8.96 & 2.82 \\
\hline & Upper Limit (IC) & $\mathrm{IN}$ & IN & IN & IN & 7.44 & 9.11 & 3.43 \\
\hline \multirow{5}{*}{ Matrice 3} & Sample size (n) & 13 & 13 & 13 & 2 & 100 & 100 & 50 \\
\hline & Average & 24.52 & 89 & 22.56 & 16.36 & 7.12 & 8.88 & 3.28 \\
\hline & Mean standard error & 0.24 & 9 & 2.91 & IN & 0.03 & 0.04 & 0.03 \\
\hline & Lower limit (IC) & 24.01 & 70 & 16.22 & IN & 7.05 & 8.80 & 3.22 \\
\hline & Upper Limit (IC) & 25.04 & 109 & 28.89 & IN & 7.18 & 8.96 & 3.34 \\
\hline \multirow{5}{*}{ Matrice 4} & Sample size (n) & 14 & 14 & 14 & 14 & 100 & 100 & 50 \\
\hline & Average & 30.34 & 154 & 52.1 & 21.0 & 7.67 & 9.20 & 3.82 \\
\hline & Mean standard error & 0.19 & 3 & 1.5 & 0.4 & 0.03 & 0.04 & 0.06 \\
\hline & Lower limit (IC) & 29.93 & 147 & 48.8 & 20.1 & 7.61 & 9.11 & 3.69 \\
\hline & Upper Limit (IC) & 30.74 & 162 & 55.4 & 21.8 & 7.74 & 9.28 & 3.95 \\
\hline \multirow{5}{*}{$\begin{array}{l}\text { Average } \\
\text { Overall }\end{array}$} & Sample size (n) & 34 & 34 & 34 & 15 & 399 & 399 & 146 \\
\hline & Average & 27.19 & 112 & 33.08 & 20.3 & 7.50 & 9.06 & 3.52 \\
\hline & Mean standard error & 0.49 & 7 & 3.19 & 0.6 & 0.02 & 0.02 & 0.03 \\
\hline & Lower limit (IC) & 26.21 & 98 & 26.70 & 18.9 & 7.46 & 9.01 & 3.45 \\
\hline & Upper Limit (IC) & 28.16 & 127 & 39.45 & 21.6 & 7.55 & 9.10 & 3.58 \\
\hline
\end{tabular}

FM $100=$ mass of 100 fruits; TS $100=$ total number of seeds in 100 fruits; $\% \mathrm{HS}=$ percentage of healthy seeds in 100 fruits; MS1000 = mass of 1,000 seeds; $\mathrm{FL}=$ fruit main axis length; $\mathrm{FD}=$ fruit diameter; $\mathrm{MSD}=$ mean seed diameter; confidence interval $=0.05 ; \mathrm{IN}=$ insufficient number of repetitions. 


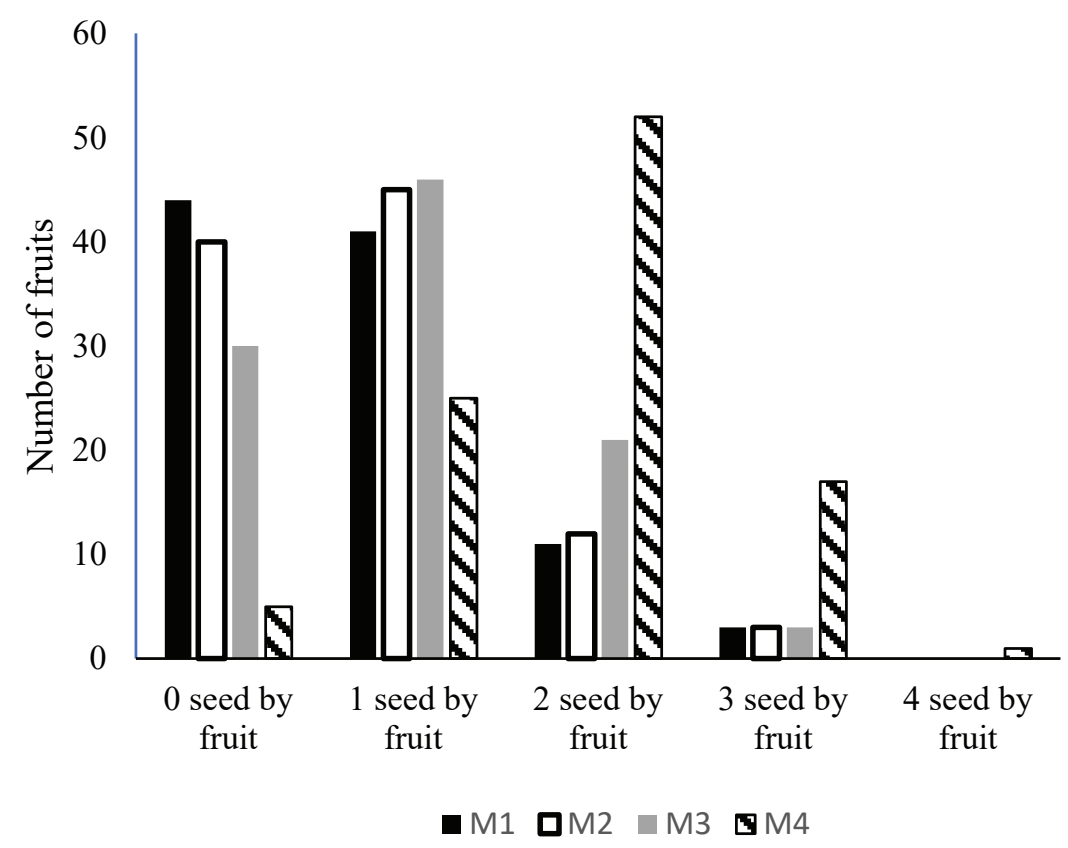

Figure 3. Number of seeds per fruit and per matrice of Astrocasia jacobinensis collected in the Environmental Protection Area of Lago de Pedra do Cavalo, Bahia State, Brazil.

Table 3. Germination performance of Astrocasia jacobinensis according to fruits collor.

\begin{tabular}{|c|c|c|c|c|c|c|c|c|c|}
\hline & AT (dias) & GT & $\mathbf{U}_{8416}$ & $\begin{array}{l}\text { APL } \\
\text { (cm) }\end{array}$ & $\begin{array}{l}\mathrm{RL} \\
(\mathrm{cm})\end{array}$ & $\begin{array}{c}\text { Synchronization } \\
\text { index }\end{array}$ & $\% G$ & $\begin{array}{c}\% \\
\text { Normals }\end{array}$ & $\mathbf{N} / \mathbf{G}$ \\
\hline Seeds of brown fruits & $9.4 \mathrm{~A}$ & $0.11 \mathrm{~B}$ & $4.00 \mathrm{~A}$ & $0.43 \mathrm{~B}$ & $0.45 \mathrm{~B}$ & $2.07 \mathrm{~A}$ & $21.3 \mathrm{~B}$ & $16.25 \mathrm{~B}$ & $0.76 \mathrm{~A}$ \\
\hline Seeds of green fruits & $8.3 \mathrm{~B}$ & $0.12 \mathrm{~A}$ & $3.75 \mathrm{~A}$ & $1.53 \mathrm{~A}$ & $1.66 \mathrm{~A}$ & $2.48 \mathrm{~A}$ & $82.5 \mathrm{~A}$ & $70.00 \mathrm{~A}$ & $0.85 \mathrm{~A}$ \\
\hline Calculated $\mathrm{t}$ & 3.89 & 3.95 & 0.34 & 5.95 & 4.40 & 1.78 & 8.5 & 5.57 & 1.04 \\
\hline Significance level & 0.01 & 0.01 & 0.75 & 0.002 & 0.01 & 0.17 & 0.002 & 0.001 & 0.35 \\
\hline
\end{tabular}

$\mathrm{AT}=$ average time; $\mathrm{GT}=$ germination time $\mathrm{U}_{8416}=$ time intervals between $16 \%$ and $84 \%$ viable seed germination; $\mathrm{APL}=$ average aerial part length; $\mathrm{RL}=$ roots length; $\% \mathrm{G}=$ percentage of germination; $\%$ Normal = percentage of normal seedlings; $\mathrm{N} / \mathrm{G}=$ normal on germinated seeds ratio. Means followed by the same letter in the column do not differ statistically by the t-test $(\alpha<0.05)$.

The temperatures that favored germination were 25 , 30 and the alternating $25-30^{\circ} \mathrm{C}$, as confirmed by the smaller germination time, shorter time intervals between $16 \%$ and $84 \%$ of viable seed germination $\left(\mathrm{U}_{8416}\right)$, lower rates of synchronization and high germination rates (Table 4).

Temperatures 25 and $30{ }^{\circ} \mathrm{C}$ favored seed vigor expression (Table 5), especially at $30^{\circ} \mathrm{C}$.
Except at $15^{\circ} \mathrm{C}$, that germination began at 24 days, at the other temperatures germination started between four and six days (Figure 4).

Stabilization of germination occurred at 13 days when at $25^{\circ} \mathrm{C}$; when 24 days at $30^{\circ} \mathrm{C}$, although at 17 days it reached $73 \%$ of a total of $74 \%$ of germinated seeds; at 16 days when at $35^{\circ} \mathrm{C}$; at 15 days when at $25-30^{\circ} \mathrm{C}$ and at 20 days when at $15-30{ }^{\circ} \mathrm{C}$ (Figure 4 ). 
Table 4. Germination performance of Astrocasia jacobinensis seeds under different temperatures.

\begin{tabular}{cccccc}
\hline Temperatures $\left({ }^{\circ} \mathbf{C}\right)$ & Ln (Average time) & germination rate & $\mathbf{\% ~ G}$ & $\mathbf{U}_{8416}$ & Synchronization index \\
\hline 15 & $3.73(41.59) \mathrm{A}$ & $1.16(0.02) \mathrm{D}$ & $68.0 \mathrm{~A}$ & $16.3 \mathrm{~A}$ & $3.4 \mathrm{~A}$ \\
25 & $2.05(7.75) \mathrm{D}$ & $0.36(0.13) \mathrm{A}$ & $62.0 \mathrm{~A}$ & $3.0 \mathrm{C}$ & $2.3 \mathrm{C}$ \\
30 & $2.10(8.22) \mathrm{D}$ & $0.35(0.12) \mathrm{A}$ & $74.0 \mathrm{~A}$ & $3.5 \mathrm{C}$ & $2.3 \mathrm{C}$ \\
35 & $2.28(9.79) \mathrm{C}$ & $0.32(0.10) \mathrm{B}$ & $67.0 \mathrm{~A}$ & $6.0 \mathrm{~B}$ & $2.8 \mathrm{~B}$ \\
$25-30$ & $2.12(8.36) \mathrm{D}$ & $0.35(0.12) \mathrm{A}$ & $68.0 \mathrm{~A}$ & $3.3 \mathrm{C}$ & $2.4 \mathrm{C}$ \\
$15-30$ & $2.54(12.71) \mathrm{B}$ & $0.28(0.08) \mathrm{C}$ & $75.0 \mathrm{~A}$ & $5.8 \mathrm{~B}$ & $2.9 \mathrm{~B}$ \\
CV (\%) & 2.33 & 2.97 & 15.8 & 24.6 & 10.73 \\
Significance level & $2 * 10^{-16}$ & $2 * 10^{-16}$ & 0.58 & $2.4 * 10^{-9}$ & $8.7 * 10^{-5}$ \\
\hline
\end{tabular}

$\mathrm{Ln}=$ Neperian Logarithm of the mean germination time; $\% \mathrm{G}=$ percentage of germination; $\mathrm{U}_{8416}$ time intervals between $16 \%$ and $84 \%$ of viable seed germination. Averages in columns followed by the same letter do not differ statistically by the Scott-Knott test $(\alpha<0.05)$. CV $=$ coefficient of variation. Values in parentheses refer to untransformed data.

Table 5. Seedlings development of Astrocasia jacobinensis seeds under different temperatures.

\begin{tabular}{ccccc}
\hline Temperatures $\left({ }^{\circ} \mathrm{C}\right)$ & Normal $(\mathbf{\%})$ & APL $(\mathbf{c m})$ & $\mathbf{( c m )}$ & Ratio N/G \\
\hline 15 & $27.0 \mathrm{~B}$ & $0.30 \mathrm{C}$ & $0.49(0.25) \mathrm{C}$ & $0.38 \mathrm{C}$ \\
25 & $55.0 \mathrm{~A}$ & $1.21 \mathrm{~A}$ & $0.98(0.96) \mathrm{B}$ & $0.90 \mathrm{~A}$ \\
30 & $63.0 \mathrm{~A}$ & $1.31 \mathrm{~A}$ & $1.17(1.38) \mathrm{A}$ & $0.86 \mathrm{~A}$ \\
35 & $2.0 \mathrm{C}$ & $0.04 \mathrm{C}$ & $0.12(0.03) \mathrm{D}$ & $0.03 \mathrm{D}$ \\
$25-30$ & $52.0 \mathrm{~A}$ & $1.00 \mathrm{~B}$ & $0.97(0.96) \mathrm{B}$ & $0.76 \mathrm{~B}$ \\
$15-30$ & $56.0 \mathrm{~A}$ & $0.74 \mathrm{~B}$ & $0.94(0.90) \mathrm{B}$ & $0.75 \mathrm{~B}$ \\
\hline $\mathrm{CV}(\%)$ & 21.9 & 23.3 & 15.8 & 14.95 \\
Significance level & $1.5^{*} 10^{-7}$ & $2.2^{*} 10^{-8}$ & $2.8^{*} 10^{-9}$ & $2.8^{*} 10^{-10}$ \\
\hline
\end{tabular}

Normal $(\%)=$ percentage of normal seedlings; $\mathrm{APL}=$ aerial and $\sqrt{ } \mathrm{RL}$ square root of root length; ratio $\mathrm{N} / \mathrm{G}=$ normal on germinated ratio. Averages in columns followed by the same letter do not differ statistically by the Scott-Knott test $(\alpha<0.05)$. Values in parentheses refer to untransformed data.

\section{Discussion}

Seeds production was different among matrices, with the best results for matrice 4 (Table 2). Seeds production among trees of the same species within a population may vary widely, since each tree is grown in a specific condition of soil, water availability and microclimate, which may influence flowering and fruiting (Mendonça et al., 2014). The verification of the trees capacity to supply propagules is important for planning the activities of seeds collection to supply restoration and silviculture projects.

The color of the fruit, due to the easiness of visualization, is a characteristic used to indicate seeds maturation (Borges et al., 2016; Silva et al., 2017). In some species of dry fruits, results showed that the brown color is associated with the maturation point and, consequently, better performance of seeds germination (Aquino et al., 2006; Guimarães \& Barbosa, 2007; Silva et al., 2009). However, for Astrocasia jacobinensis the seeds of green fruits had higher germination performance $(82.5 \%)$ than those obtained from brown fruits $(21.3 \%)$, corroborating with the study of Aguiar et al. (2007) with Caesalpinia echinata Lam. and Silva et al. (2017) with Jatropha curcas L. The divergent results point to a need to determine precisely the germination potential based on fruit color for each species, since the coloration may be a morphological indicator of maturation. In addition, future studies should be carried out aiming at understanging the physiological maturation of $A$. jacobinensis seeds, in order to better define the point of fruit collection for propagation.

The temperature of $15^{\circ} \mathrm{C}$ did not affect germination rate of $A$. jacobinensis seeds, however, normal seedling formation impaired (Table 4). Although the low temperature did not affect the emission of the radicle, the effects may have started in the post-seminal development, negatively influencing the seedlings formation (Table 5). 
A
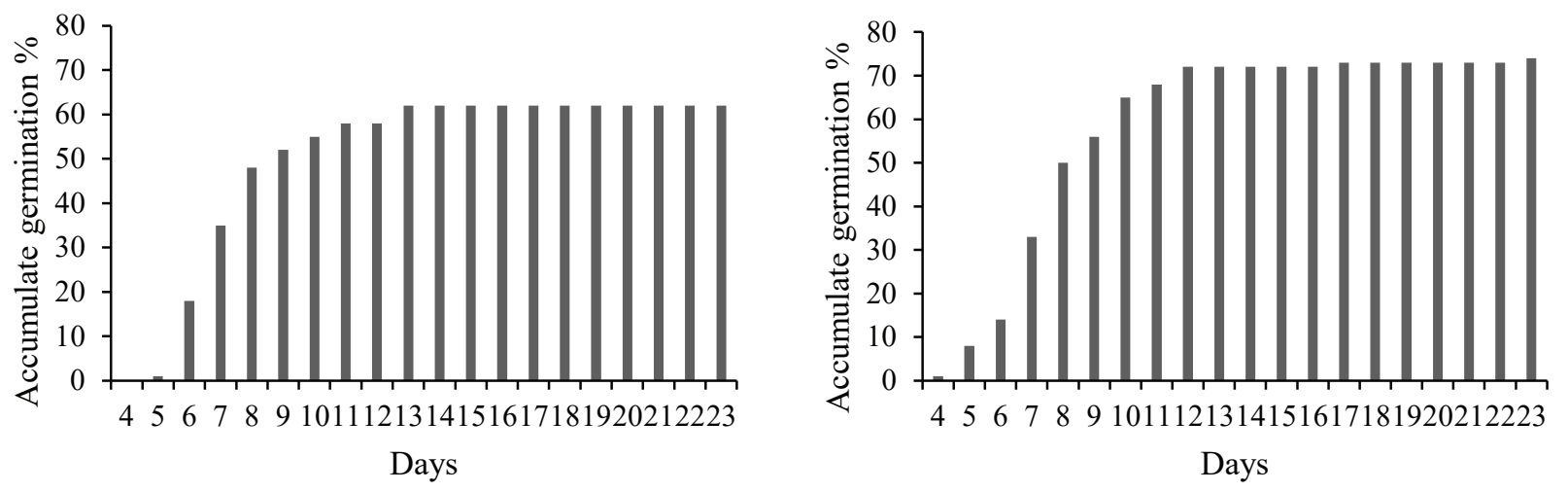

C
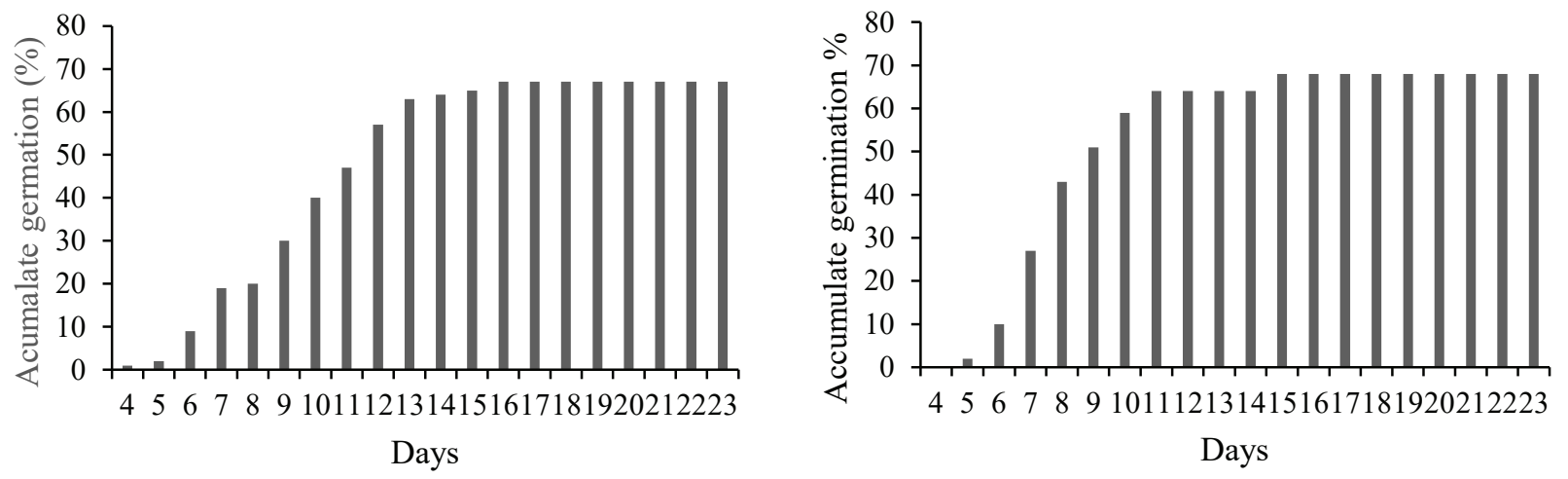

$\mathrm{E}$

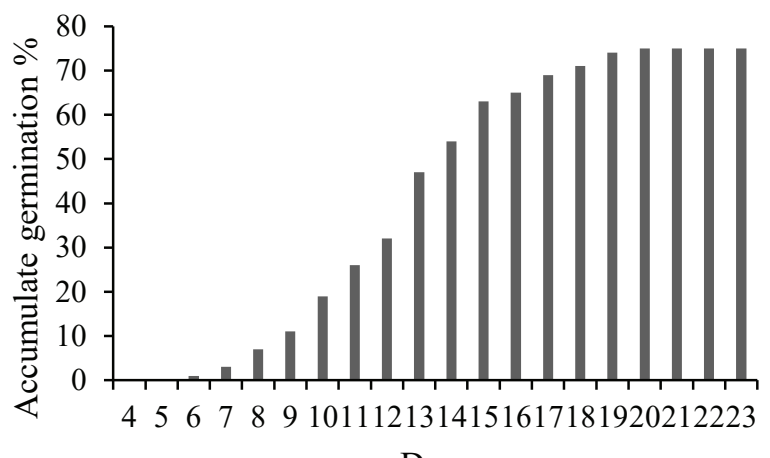

Days

Figure 4. Germination of Astrocasia jacobinensis seeds over time in function of different temperatures (A) $25^{\circ} \mathrm{C}$; (B) $30^{\circ} \mathrm{C}$; (C) $35^{\circ} \mathrm{C}$ (D) $25-30^{\circ} \mathrm{C}$; (E) $15-30^{\circ} \mathrm{C}$. 
Seedlings share the same reserves that were mobilized during seed germination until they can initiate photosynthesis (Zhong et al., 2002). Thus until assuming its autotrophic function, the growth is supplied by the carbohydrates derived from the seed reserves. In spite of being considered as a post-germinative event, the start of reserve mobilization occurs before the radicle protrusion (Castro et al., 2004). Probably, in A. jacobinensis the enzymes related to reserves mobilization for seedling development were affected by low temperature $\left(15^{\circ} \mathrm{C}\right)$, compromising tissues formation and generating abnormalities.

Brancalion et al. (2010) studied the ecological aspects regarding the optimum temperature in the germination of 272 Brazilian tree species, and indicated $25^{\circ} \mathrm{C}$ for the Atlantic Forest Biome species. Melo et al. (2017) showed that the highest germination rates of Eriotheca gracilipes (K. Schum.) A. Robyns were obtained at 25 or $30{ }^{\circ} \mathrm{C}$. González-Rivas et al. (2009) studied germination and establishment of three species from neotropical forests under different temperature and light regimes and observed that for seeds of Cedrela odorata L. germination was higher at 20,25 and $35^{\circ} \mathrm{C}$ and the optimum temperature for Guaiacum sanctum L. was 20 and $25^{\circ} \mathrm{C}$. In general, the results found for $A$. jacobinensis corroborate with the recommendation of these authors, considering that 25 and $30{ }^{\circ} \mathrm{C}$ presented the best germination performance.

The optimum germination temperature is usually between the minimum and maximum temperatures considering the period of emergence and establishment of seedlings of the species origin region or site (Gualtieri \& Fanti, 2015). In the Environmental Protection Area of Lago de Pedra do Cavalo, where A. jacobinensis seeds were collected, the favorable propagation period is from April to July, in which the minimum temperatures range from 16 to $20^{\circ} \mathrm{C}$ and the maximum from 25 to $31^{\circ} \mathrm{C}$ (Instituto Nacional de Meteorologia, 2017).

The uniformity and speed of germination evaluated on the basis of the mean germination time and the time intervals between $16 \%$ and $84 \%$ of viable seed germination (Bewley et al., 2013), as well as the synchronization index (Santana \& Ranal, 2004) are aspects that must be considered in studies with the objective of determining the optimal germination condition. However, for native species, which did not go through domestication, the first aspect to be evaluated is the formation of normal seedlings, with the other variables considered less important in decision making to determine optimal germination conditions. For A. jacobinensis temperatures of 25 and $30^{\circ} \mathrm{C}$ were among those that provided higher percentage of normal seedlings, lower average germination times, $\mathrm{U}_{8416}$ and synchronization indexes.

For germination tests with the objective of attesting the quality of seed lots, the Brazilian Analysis Rules (Brasil, 2009, 2013) stipulate numbers and intervals between the counts as well as the germination performance temperatures. However, A. jacobinensis is not listed among the species covered by these rules. Considering the distribution of germination over time (Figure 4), at the temperature of $25^{\circ} \mathrm{C}$, the recommendation to perform two counts on the fifth and thirteenth day would be enough to characterize the germination of seed lots of this species. For the temperature of $30^{\circ} \mathrm{C}$ the two counts can be carried out on the fifth and seventeenth day.

\section{Conclusions}

Green fruits should be selected when collecting seeds of Astrocasia jacobinensis, as they present greater germination performance and vigor.

It is recommended temperature of $25^{\circ} \mathrm{C}$ or $30^{\circ} \mathrm{C}$ to conduct germination tests of $A$. jacobinensis seeds.

\section{Financial Support}

The financial support was granted by Institute of Environment and Water Resources - INEMA through funding of the Reference Center for Forest Restoration of the Atlantic Forest Biome - CRRF/MA.

\section{References}

Aguiar, F. F. A. et al. Maturação de frutos de Caesalpinia echinata Lam. Pau-Brasil. Revista Árvore, v. 31, n. 1, p. 1-6, 2007. DOI: 10.1590/S0100-67622007000100001.

Alvares, C. A. et al. Köppen's climate classification map for Brazil. Meteorologische Zeitschrift, v. 22, n. 6, p. 711-728, 2013. DOI: 10.1127/0941-2948/2013/0507.

Aquino, N. F. et al. Dormência de sementes de Peltophorum dubium (SPRENGEL.) TAUBERT colhidas em diferentes estádios de desenvolvimento. Scientia Agraria Paranaensis, v. 5, n. 2, p. 31-37, 2006.

Associação Plantas do Nordeste. Estatística florestal da Caatinga. Recife, 2015. v. 2. 142 p. 
Bewley, J. D. et al. Seeds: physiology of development germination and dormancy. New York: Springer, 2013. 392 p.

Borges, K. C. F. et al. Coloração do fruto e substrato na emergência e no crescimento de plantas de Eugenia calycina Cambess. Floresta e Ambiente, v. 23, n. 4, p. 544-554, 2016. DOI: 10.1590/21798087.144215.

Brancalion, P. H. S. et al. Temperatura ótima de germinação de sementes de espécies arbóreas brasileiras. Revista Brasileira de Sementes, v. 32, n. 4, p. 15-21, 2010. DOI: 10.1590/S010131222010000400002 .

Brasil. Ministério da Agricultura, Pecuária e Abastecimento. Secretaria de Defesa Agropecuária. Instruções para análise de sementes de espécies florestais. Brasília, DF, 2013. 98 p.

Brasil. Ministério da Agricultura, Pecuária e Abastecimento. Secretaria de Defesa Agropecuária. Regras para análise de sementes. Brasília, DF, 2009. 399 p.

Brasil. Ministério da Integração Nacional. Companhia de Desenvolvimento dos vales do São Francisco e do Parnaíba. Estudo de impacto ambiental (EIA) do aproveitamento múltiplo dos recursos naturais na área de influência do sistema Xingó, nos estados de Sergipe e Bahia. Brasília, DF, 2012. v. 2. 256 p.

Cardoso, D. B. O. S. et al. Composição florística e análise fitogeográfica de uma floresta semidecídua na Bahia, Brasil. Rodriguésia, v. 60, n. 4, p. 1055-1076, 2009. DOI: 10.1590/21757860200960416.

Castro, R. D. et al. Embebição e reativação do metabolismo. In: Ferreira, A. G. \& Borghetti, F. Germinação: do básico ao aplicado. Porto Alegre: Artmed, 2004. p. 149-162.

Flora do Brasil: Phyllanthaceae. In: Flora do Brasil 2020 em construção. Rio de Janeiro: Jardim Botânico do Rio de Janeiro, [2017]. Disponível em: <http://floradobrasil.jbrj.gov.br/reflora/ floradobrasil/FB38457>. Acesso em: 16 fev. 2017.

Gonzalez-Rivas, B. et al. Seed germination and seedling establishment of Neotropical dry forest species in response to temperature and light conditions. Journal of Forestry Research, v. 20, n. 2, p. 99-104, 2009. DOI: $10.1007 / \mathrm{s} 11676-009-0018-\mathrm{y}$.

Gordillo, M. M. et al. Los géneros de la familia Euphorbiaceae em México. Serie Botânica, v. 73, n. 2, p. 155-281, 2002. DOI: 10.13140/RG.2.1.3813.7762.

Gualtieri, S. C. J. \& Fanti, S. C. Germinação de sementes: ecofisiologia da germinação de sementes. In: Piña-Rodrigues, F. C. M. et al. Sementes florestais tropicais: da ecologia à produção. Londrina: ABRATES, 2015. p. 259-275.

Guedes, R. S. et al. Teste de comprimento de plântula na avaliação da qualidade fisiológica de sementes de Erythrina velutina Willd. Semina: Ciências Agrárias, v. 30, n. 4, p. 793-802, 2009. DOI: 10.5433/1679-0359.2009v30n4p793.

Guimarães, D. M. \& Barbosa, J. M. Coloração dos frutos como índice de maturação para sementes de Machaerium brasiliense Vogel (Leguminosae - Fabaceae). Revista Brasileira de Biociências, v. 5, n. 2, p. 567-569, 2007.

Instituto Nacional de Meteorologia. Brasília, DF, 2017. Disponível em: < http://www.inmet.gov.br/>. Acesso em: 21 set. 2017.
Jiménez, J. \& Gordillo, M. M. Una especie nueva del género Astrocasia (Euphorbiaceae) del estado de Guerrero, México. Acta Botánica Mexicana, n. 55, p. 1-5, 2001. DOI: 10.21829/ abm55.2001.869.

Juncá, F. A. et al. Biodiversidade e conservação da Chapada Diamantina. Brasília, DF: Ministério do Meio Ambiente, 2005. $411 \mathrm{p}$.

Lima, T. M. et al. Influence of temperature and photoperiod on the germination of Senegalia bahiensis seeds. Semina: Ciências Agrárias, v. 38, p. 1103-1114, 2017. DOI: 10.5433/1679-0359.2017.

Melo, P. A. F. R. et al. Substrates and temperatures in the germination of Eriotheca gracilipes seeds. Revista Ciência Agronômica, v. 48, n. 2, p. 303-309, 2017. DOI: 10.5935/1806-6690.20170035.

Mendonça, A. V. R. et al. Produção e armazenamento de sementes de Poincianella pyramidalis (Tul.) L. P. Queiroz, em resposta a diferentes ambientes de coleta. Agrária, v. 9, p. 413-419, 2014. DOI: 10.5039 /agraria.v9i3a2589.

Oliveira, L. M. de. Teste de germinação de sementes de Peltophorum dubium (Sprengel) Taubert - Fabaceae. Floresta, v. 38, n. 3, p. 545551, 2008. DOI: 10.5380/rf.v38i3.12425.

Oliveira, A. C. C. Biometria e germinação das sementes de Courataru macrosperrma A.C. Smith (Lecythidaceae) e Schizolobium amazonicum Huber ex Ducke (Fabaceae). 2009. 94 f. Dissertação (Mestrado em Ciências Ambientais) - Universidade do Estado de Mato Grosso, Cuiabá.

Oliveira Filho, A. T. et al. Compilação e caracterização das espécies arbóreas da flora nativa de Minas Gerais. In: Oliveira Filho, A. T. \& Scolforo, J. R. Inventário florestal de Minas Gerais: espécies arbóreas da flora nativa. Lavras: UFLA, 2008. p. 1-8.

R Development Core Team. R: R version 3.1.3 (2015-03-09). 2015. Available at: $<$ http://www.rproject.org $>$. Accessed in: 10 Maio 2017.

Ribeiro, R. T. M \& Loiola, M. I. B. Flora do Ceará: Phyllanthaceae Martinov. In: CONGRESSO NACIONAL DE BOTÂNICA, 67., 2016, Vitória. Conectando diversidades, revelando o desconhecido. Vitória: [s.n.], 2016.

Santana, D. G. \& Ranal, M. A. Análise da germinação: um enfoque estatístico. Brasília, DF: Ed UnB, 2004. 247 p.

Silva, A. P M et. al. Can current native tree seedling production and infrastructure meet an increasing forest restoration demand in Brazil? Restoration Ecology, v. 25, n. 4, p. 509-515, 2017. DOI: 10.1111/rec.12470.

Silva, L. B. et al. Estádios de colheita e repouso pós-colheita dos frutos na qualidade de sementes de mamoneira. Revista Brasileira de Sementes, v. 31, n. 1, p. 50-59, 2009. DOI: 10.1590/S010131222009000100006 .

Silva, L. J. et al. The effect of fruit maturity on the physiological quality and conservation of Jatropha curcas seeds. Revista Ciência Agronômica, v. 48, n. 3, p. 487-495, 2017. DOI: 10.5935/18066690.20170057.

Silva, M. J. \& Sales, N. F. O gênero Phyllanthus L. (Phyllantheae Euphorbiaceae Juss.) no bioma Caatinga do estado de Pernambuco - Brasil. Rodriguésia, v. 84, n. 55, p. 101-126, 2004. 
Siqueira-Filho, J. A. et al. Relatório 6: inventário, monitoramento e resgate da flora em áreas de influência direta e indireta do Projeto São Francisco. Petrolina: CRAD/UNIVASF, 2009. 85 p.

Souza, J. S. et al. Flora das APAS Lago Pedra do Cavalo e JoanesIpitanga. In: Mendonça, A. V. R. et al. (Org.). Propagação de espécies nativas florestais nativas da Bahia. Cruz das Almas, BA, 2018. p. 428-446.
Webster, G. L. Revision of Astrocasia (Euphorbiaceae). Systematic Botany, v. 17, n. 2, p. 311-323, 1992. DOI: 10.2307/2419525.

Zhong, X. et al. Temperature dependence of seedling establishment of a perennial, Dioscorea tokoro. Journal of Plant Research, v. 115, p. 55-57, 2002. DOI: 10.1007/s102650200008. 